\title{
BUSINESS ENVIRONMENTS AND ENTREPRENEURIAL PERFORMANCE: A CASE STUDY OF BOTTLED WATER COMPANIES IN RIVERS STATE
}

\author{
Joseph-Wakama Josephine \\ Department of Management, University of Port Harcourt Business School \\ B. Chima Onuoha \\ Department of Management, University of Port Harcourt
}

Article DOI: $\underline{\text { https://doi.org/10.36713/epra5353 }}$

\begin{abstract}
The paper examined the impact of business environment on the entrepreneurial performance of bottled water companies in Nigeria. Literature on the business environment and entrepreneurial performance in Nigeria is also presented. Second, on the basis of a sample of 3 bottled water companies with a sample size of 105, a questionnaire was developed to gather information from respondents, using a correlation analysis, the collected and analysed data. In conjunction with measures such as productivity and customer satisfaction, dimensions such as the internal environment and the external environment include a moderating variable which is organizationally structured to capture all aspects of the model. The study found that the internal environment, a proxy for business environments, shows a positive and significant relationship with productivity as the best measure for the environment in bottled water companies in Port Harcourt, and the external environment shows a positive and meaningful relationship with productivity as the best measure for the environment in bottled water companies in Port Harcourt It is recommended that, as far as possible, the management of Bottled Water companies should provide employees with an attractive working environment and provide opportunities for development to enhance employee career growth and make them satisfied to remain in the organization and plan strategically for changes to the external environment. The study concluded that there was an impact on entrepreneurial performance on the external business environment, political, economic, technological and sociocultural, etc. To identify opportunities and threats to their company and organization, organizations should therefore understand the implications of the entrepreneurial performance of their business activities.

KEYWORDS: Business Environment, Internal environment, external environment, Entrepreneurial performance, Bottle water companies

\section{INTRODUCTION}

Business is considered to be a human activity within and across a geographical area concerned with the production and distribution of goods and services (Ajayi, 2018). It is a social tool through which societies organize their financial efforts. In particular, business is the sum total of the organized efforts of individuals engaged in trade and industry to provide the necessary goods and services to maintain or improve the standard of living and quality of life to which individuals may aspire. The word "environment" does not necessarily mean physical surroundings in management, but is used to describe all the influences affecting the individual organization. The business environment is used to mean anything that a business organization is surrounded by. It affects the company's decisions, strategies, procedures and performance. The environment is made up of social, technological, economic,
\end{abstract}




\section{EPRA International Journal of Environmental Economics, Commerce and Educational Management Journal DOI: 10.36713/epra0414 |ISI I.F Value: 0.815|SJIF Impact Factor (2020): 7.572 \\ Volume: 7| Issue: 3 | October 2020}

legal and political factors outside the control of business (STEP). It offers opportunities or poses threats to the organization. The modern business of today is dynamic, the most dynamic shift has been that of competitive pressure if there is any word that can best be used to describe the business of today (Buchanan \& Huczynski, 2019). In order to adapt to the dynamic and unpredictable nature of the business environment, competitors must apply one strategy or another. Nigeria's performance is based on factors such as low sales, high production costs, low capital utilization, lack of foreign exchange for needed inputs and materials, poor power supply, and low quality of goods and services, among others, in Nigeria's modern business environment. Economic activity is hindered by these environmental forces. The World Bank believes that improving the enabling environment results in higher levels of investment in the private sector, more wealth, job creation and alleviation of poverty (Adeoye 2013). Since the oil boom of the 1960s and early 1970s, the Nigerian business environment has seen a great deal of change. In the early 1980 s, austerity measures and the structured adjustment program in the late 1980s of the company act of the 1960s Allied Material Decree in the 1990s undoubtedly brought the opportunities to be exploited by some companies in the 1980s or the problems that inhibit the survival of so many companies (Ogundele, 2013). The relationship between business and its environment is one of mutuality. Therefore, the above picture presents the need to examine the impact of the external business environment on the business performance of Nigeria's bottled water sector, which is the focus of this report. A complex, multi-focused dynamic is the environment in which business organizations operate and has a far-reaching impact on that organisation. The environment tends to shape the organization's outlook and goals by imposing constraints on them. In the environment of objective organizations, these constraints could take the form of competition, which sets a limit on the objectives set by the organization. All of these environments provide multiple contexts that affect how the company works and how and what it generates (Buchanan \& Huczynski, 2019). It has been found that these environmental forces are capable of preventing or facilitating entrepreneurial activity in any economy. The World Bank believes that improving the environment leads to higher levels of investment in the private sector, more wealth, the creation of jobs and the alleviation of poverty (Adeoye, 2013). The connection between business and its environment is one of mutuality; that is, the environment places pressure on the company, while the company, in turn, affects certain aspects of its environment. Therefore, the above image shows the need to examine the impact of the business environment on the entrepreneurial performance of the Port Harcourt bottled water companies, which is the focus of this report.

\section{Objectives of the study}

The aim of this study is the identification of the influence of business environments and entrepreneurial performance in bottled water companies in Nigeria; while the specifically Objectives include:

i. To examine the relationship between internal environment and productivity of bottled water companies in Nigeria.

ii. To determine the Relationship between external environment and productivity of bottled water companies in Nigeria.

iii. To investigate the Relationship between Internal environment and customer satisfaction of bottled water companies in Nigeria.

iv. To examine the Relationship between external environment and customer satisfaction of bottled water companies in Nigeria.

v. To investigate the moderating role of organizational structure on the association between business environment and entrepreneurial performance of sampled bottled water companies in an organization.

\section{Research Hypotheses}

The proposed research work at hand will be guided by the following hypotheses stated in their null form.

$\mathbf{H}_{\mathbf{o} 1}$ : There exists no significant relationship between internal environment and Productivity of bottled water companies in Nigeria.

$\mathbf{H}_{\mathbf{o} 2}$ : There is no significant relationship between External environment and Productivity of bottled water companies in Nigeria.

$\mathbf{H}_{\mathbf{0} 3}$ : There is no significant relationship between internal environment and Customer satisfaction of bottled water companies in Nigeria.

$\mathbf{H}_{\mathrm{o} 4}$ : There is no significant relationship between External environment and Customer satisfaction of bottled water companies in Nigeria.

$\mathbf{H}_{\mathbf{o} 5}$ : There is no significant influence of Organizational Structure on the association between Business Environment and Entrepreneurial performance of sampled bottled water companies in an Organization. 


\section{EPRA International Journal of Environmental Economics, Commerce and Educational Management

The organization faces a turbulent and rapidly changing environment, due to poor entrepreneurial performance, delays in the availability of resources, political interference and variations in economic situations (Kobia \& Mohamed, 2006). Tachera (2007) postulates that organizational processes are affected differently by factors in the external environment. This can be based on the assumption that entrepreneurial performance is impacted by the external environment. The overall goal is that business environments have no impact on the performance of entrepreneurship.

This study would not only add to the work done in this field, but would also lead to further research into the implementation of Work Environment Studies on Entrepreneurship Performance in selected organizations in Port Harcourt, Rivers State, which would benefit scholars who intend to write similar papers and add to the current knowledge gap. It will help them understand the vital role and impact of the work environment and its appropriate teaching, decision-making and better incentives for employee motivation and improvement styles, and will demonstrate how they can be better equipped to deal with the inevitability of sample entrepreneurial performance.

\section{Theoretical Foundation}

\section{LITERATURE REVIEW}

\subsubsection{Person Environment Fit Theory}

This theory, developed in 1935 by Lewis, is based on interactions between humans / organizations and the environment (Brewer \& Macmahan, 2004). The PE Fit Theory is the framework for work stress research that is most widely accepted (Jackson \& Maslach, 1982). The overall basic premise of fit is that results, such as stress, are a function of the individual's interaction with their work environment.

The PE Fit Theory notes that whether a situation is stressful for the individual is determined by the interaction between the individual and the work environment (Keller, 2001). Stress can also occur if the person identifies the discrepancy between the reality (objective) of the working environment and the individual's perception of the working environment (subjective) (Kristof-Brown \& Jansen, 2007). Lack of fit may also occur when the requirements placed on an individual employee conflict with his or her ability to meet the requirements that lead, in turn, to work stress. The PE Fit Theory consists of an individual fit for his vocation, organization, group and job (Kristof-Brown \& Jansen, 2007). The multidimensional construction The multidimensional aspect of the PE Fit Theory makes it possible for the theory to be a better predictor of wider individual results, such as stress, withdrawal or environmental adjustment, which can ultimately lead to the burnout of an individual in the work environment.

\subsubsection{Psychological Capital Theory}

As suggested by Sweetman and Luthans, much of the organizational performance research to date has underscored the features of work and, in some instances, the balance between work and private life. Therefore, other factors of importance, such as the role of employee resources and the role of personal agency, are to some extent rejected (Tremblay \& Messervey, 2011). Personal resources can be defined as self-reliance aspects and refer to a sense of control and impact on the environment (Hobfoll, Johnson, Ennis, \& Jackson, 2003) and can be important in determining the adaptation of employees to their work environment (Hobfoll, 1989). Findings indicate that the optimism and efficiency of employees is stimulated by a resourceful work environment, which in turn makes them feel more able to control their work environment (Luthans, Avey, Avolio, Norman, \& Combs, 2006). It has also been shown that optimism and self-efficiency have an impact on employees'organizational performance (Avey, Luthans, \& Jensen, 2009; Xanthopoulou et al ., 2007) and, together with hope and resilience, have a negative impact on employees' intent to quit (Avey et al., 2009). The concept of'psychological capital' has been introduced by Sweetman and Luthans (2010). This involves personal resources such as self-efficacy, optimism, hope and resilience, which can act as a buffer between contextual requirements and organizational performance (Bothma \& Roodt, 2012). In the mediating role between psychological capital and organizational performance, a recent study found market shares (Lok, 2011), while another study found that psychological capital actually has a direct negative connection to the intention to quit (Avey, Luthans \& Youssef, 2009). The aim is to broaden the understanding of organizational performance by including personal resources in this study and to see how personal resources operate in this cognitive behavioral process.

On the concept of the business environment, various scholars have given different definitions and opinions. The business environment can be defined as a combination of internal and external variables that affect the organization's operating situation, according to the Business Dictionary (2013). Factors such as customers and suppliers, rivals and owners, enhanced technology and government legislation, markets, social and economic trends may be included in the business environment. Fermando (2017) sees the business environment as external forces, 


\section{EPRA International Journal of Environmental Economics, Commerce and Educational Management Journal DOI: 10.36713/epra0414 |ISI I.F Value: 0.815|SJIF Impact Factor (2020): 7.572 \\ Volume: 7| Issue: 3 | October 2020}

factors and institutions that are beyond business control and affect the functioning of a company, including customers, rivals, suppliers, distributors, industry trends, replacements, government activity regulation, the economy, demographics, social and cultural factors, innovations and technology. Kinuu (2014) argues that as the organization seeks legitimacy to survive and thrive in the environment, the business environment in which the organization operates exerts pressure on them from environmental pressures to respond differently.

Environmental conditions such as uncertainty, dynamism, hostility, the number of relevant components of the environment and the interpersonal relationship between these components, all of which increase the perceived complexity of management organizations (Lehner, 2004), Machuki and Aosa (2011) suggest that environmental construction should be treated as consisting of two broad aspects. An overall evaluation of the conditions that affect companies today shows that the external environment of most organizations is filled with uncertainty, according to Welch and Welch (2005). Companies must be aware of and fully understand the various manifestations of the external environment in order to successfully deal with uncertainty and attain a level of competitiveness in order to thrive. Osuagwu (2001) argues that the atmosphere has been viewed as the totality of factors that affect, influence or determine a company's operation or performance. What the organization can accomplish is determined by the environment. In short, the business environment is a combination of many tangible and non-tangible factors that, by providing a market for their products and services and also serving others as a source of resources, guarantee the success of live blood for organizations. Business is a series of collisions with the future, according to Ciano (2011), while its current challenges include convergence, corporate governance, corporate reporting, fraud, global activities, enhancement of business performance, asset management, change and people, mergers and acquisitions, risk management, values of shareholders and sustainability. He argued that, since it is neither the strongest nor the most intelligent of the species that survives, it is the one that is most adaptable to change; therefore, the companies that make up the industry have faced the need for the equivalent of self-managed surgery without insurance, esthetics or long-term health assurance.

\section{What is Business Environment?}

The environment is the complete sun of circumstances that surround us at a given time and space point, according to UBC Net Tutor Commerce (2008). It consists of interactive physical, biological and cultural component systems that are both individually and collectively interlinked. It further states that, under the conditions under which the organism must survive or maintain its life process, the environment is the total sun. It affects the growth of living forms and their development. The environment refers to anything that immediately surrounds an object and has a direct impact on it. It consists of interactive systems that are interlinked between the physical and cultural elements of business.

The business environment is also considered by Blurtit (2013) to be the conditions and forces that are permanent to the company and beyond the individual business unit, but all operate within it. The business environment is considered by Fermando (2011) to be external forces, variables and institutions beyond the control of the company and which have an impact on the functioning of the company. These include customers, rivals, suppliers, public and social, political, legal and technological variables, etc. Oyebanji (1994) defined the business environment as those variables that could influence the individual's business organization. He also stressed that, despite their differences in status, every organization must take account of the environmental, material and human resources constraints of its respective businesses and that the impact of the environment is degraded from one situation to another. The business environment has the following characteristics: (a) The business environment is the sum total of all non-company variables and has a major impact on their functioning. (b) It covers factors and forces such as consumers, rivals, manufacturers, public and social, cultural, political, technological and legal circumstances. (c) The business environment, which means that it continues to change, is dynamic in nature. (d) Changes are unforeseeable in the business environment. The exact nature of future developments and changes in the economic and social environment is very hard to predict. (e) The business environment is different from place to place, from region to region and from country to country. (2012 with Ogundele).

Adebayo et al., according to The business environment can be broadly classified into an internal and external environment (2005), with the former comprising factors or variables within the company's control and manipulation in order to achieve the set goal, while the latter includes factors beyond the company's control and manipulation. As a result, a plan must be developed by the company to help it deal with the different environmental forces (Oluremi \& Gbenga, 2011). Similarly, it is said that the nature of the business environment is classified as dynamic, stable and unstable, often assisting companies to choose suitable strategies (Ibidun and Ogundele, 2013). Adeoye (2012) argued that it is necessary to develop and implement appropriate strategies to safeguard their operations and deliver the desired results in order for companies to cope with the dynamic and quickly changing business environment. 
Likewise, Ogundele (2005) added that a firm perception of the nature of the business environment depends on its size and industry.

\section{- Types Of Environment}

Two types of environment exist, the external environment and the internal environment (Ogundele 2005), and situational factors within the organisation are included in the internal environment.

In the management process, these variables are largely the result of decision-making; they are defined within or within the organization as strengths, behaviour, resources and weaknesses. Outside an organization, an organization consists of such things, such as clients, competitors and government agencies, labor and financial firm suppliers. It consists of all the elements which exist outside the boundaries of the organisation. This paper examined the external environment.

\section{External Business Enviroment}

An attempt to understand the external forces of the organizational boundaries of business is the notion of an external business environment (Shaikh, 2010). It consists of all the elements that exist outside the organization's boundaries that have the ability to impact the organization. They are important for organizational functioning and must be carefully monitored.

\section{- Types Of External Business Environment}

The Direct (Task) Environment and the Indirect (General) Environment (Adeoye, 2012) are two kinds of external business. Direct (task) environment: These are factors that directly affect the organization's operation and performance; these are customer competitors, suppliers, government regulatory agencies, the labor union. Indirect (general) atmosphere: the elements that make up it have an indirect effect on the company. Factors such as social values, political, economic, legal, demographic behavior, natural environment, natural resources, technology, etc. usually make up this environment.

Since the colonial era, Nigeria has had a private sector economy with a lack of capital and a lack of discovery. This lack of capital led to the economic reform and orientation of state-owned corporations (more than 50 percent of share capital) between 1999 and 2007 by former President Olusegun Obasanjo, including the gradual elimination of oil sales subsidies by the national shipping line, the introduction of monetisation policies by the Economic and Financial Crime Commission (EFCC), etc. (Onjeti, 20). Today, Nigeria sees the expansion of FirstHip Indigenous Centers as a result of government privatization reforms that continue to expand the entrepreneurial sector, such as Dangote Group, Zenon Oil Group of Companies, Global com e.t.c. However, among Nigerian business people and managers, Asika (2007) has a significant impact on culture and tradition.

In addition, due to a lack of sufficient and accurate information, there is a shortage and weakness in Nigeria's distribution system. However, planning is a key component of the process of management. In Nigeria, strategic planning is rarely practiced, except for the acquisition of loan facilities as necessary. The organizational structures of the indigenous enterprise are simple and flat, Ogundele (2007) maintains. Another area in Nigeria's business environment where Nigeria has failed to fulfill its responsibilities is staffing, labor relations and business ethics. Nepotism characterizes the recruitment and selection of personnel in Nigeria today. Emphasis on the question of paper skills and age / gender.

\section{Internal Environment}

The internal environment is a component of the business environment, consisting of different elements within the organization that may or may influence the organization's choices, operations and decisions. It includes climate, culture, machinery / equipment, processes of work and work, members, practices of management and management. In other words, within an organization, the internal environment refers to the culture, members, events and factors that have the ability to influence the organization's decisions, especially the behavior of its human resources. All persons directly or indirectly linked to the organization, such as the owner, shareholders, managing director, board of directors, employees, etc., shall be referred to by the members (Machuki 2015).

\section{Entrepreneurial performance}

Two or more individuals engaged in a systematic effort to produce goods or services could be defined as an organization. In making the most of their resources and the ratio of output to input, organizations need to be effective in doing the right thing. The organization must also be efficient in doing the right thing, however, and its performance related to some specific objective performance relates to the organization's goals and to the information and formal goals of all its participants, including executives (Garino and Martin, 2007). The wise use of resources to avoid waste involves entrepreneurial performance. It follows that performance relates to how an organization reacts, understands and influences certain environmental changes, given the interaction between organizations and the environment. Unfortunately, individuals do not want to carry out those duties without a concession. For instance, they can perform their duties in a short time, if well planned. It is not necessary to forget the need to take account of 
external variables in the environment. In an important area of organizational activity, performance could be connected to a number of factors, such as increasing profitability, increasing service delivery or achieving the best result. An important result of performance is satisfaction (Ruby, 2002). The concept of OP is based on the position or assumption that Otokiti(2010) defines the combination of productive assets made up of human, physical and capital resources as the willingness of the individual to achieve the organization's goals and objectives for the main reasons of accomplishment and achievement of the organization's goal (Jones and George, 2009). However, the performance of entrepreneurship is defined as a group of individuals who come together and are willing to pursue goals and to be objective and planned or strategic. The performance of entrepreneurship is the individual group's capacity to achieve certain specific goals (Machuki 2015).

\section{Conceptual}

To carry out this study on business environments and entrepreneurial performance in bottled water companies in Porthacourt, the following dimensions (dependent) and measurements (independent variables) are shown in a conceptual form. The conceptual framework consists of three key variables, including the predictor variable; the business environment, the variable criterion; the entrepreneurial performance and the moderating variable; the organizational structure as shown below.

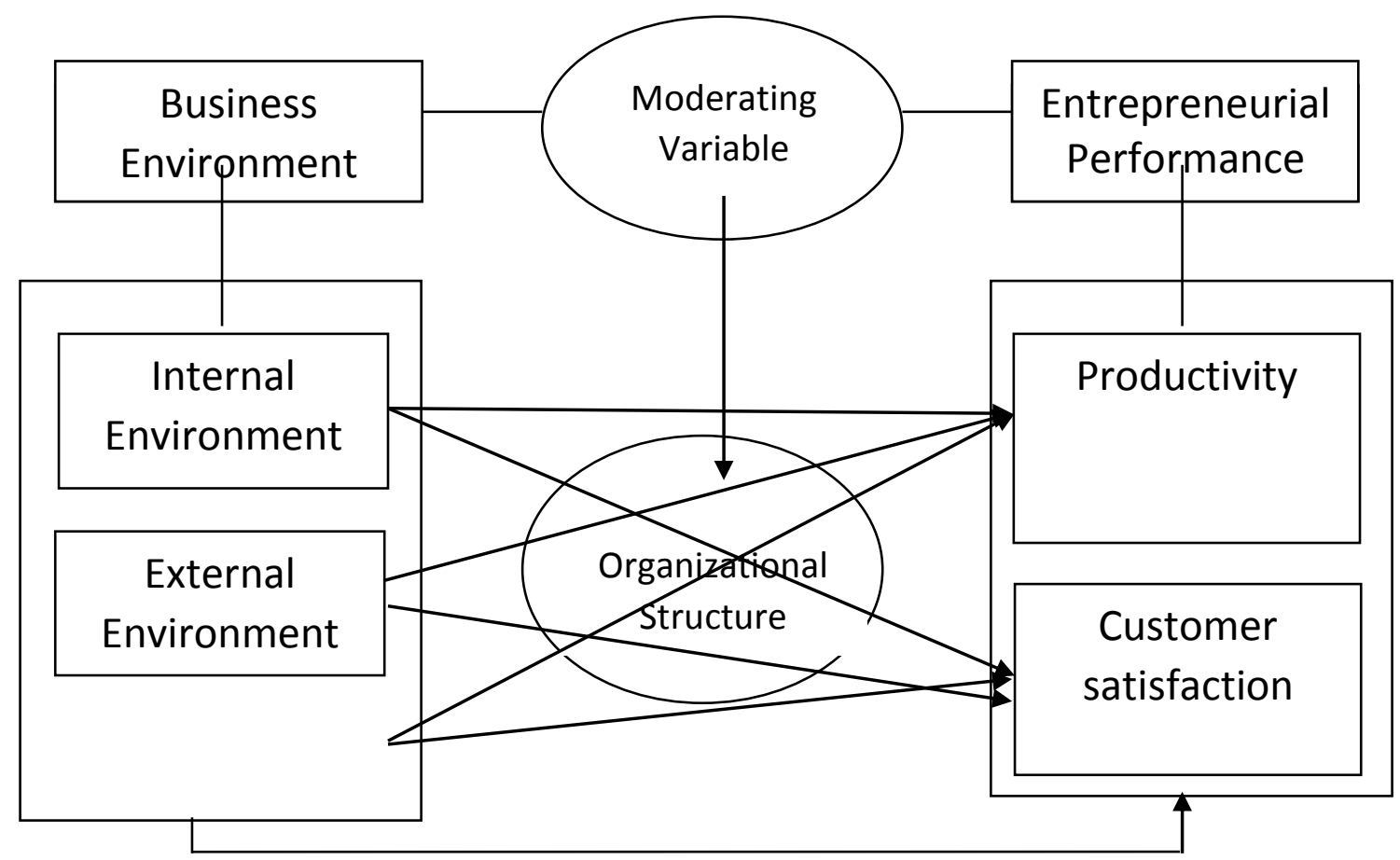

Source: Conceptualized by the Researcher (2020)

Figure 1: Framework for the study on Business Environment and Entrepreneurial performance

\subsection{Empirical Literature}

Uh, Rizwan et al. The study evaluated the determinants of entrepreneurial performance using Pakistan as a case study, using a handful of private sectors and cross-sectoral research design, and found that entrepreneurial performance or retention in an organization or work environment is largely up to the level of commitment.

The relation between social intelligence and entrepreneurial performance among hospitality industry organizations was investigated by Eketu and Ogbu (2015). A cross-sectional survey is being used in the study. Out of 159 hotels registered with the Ministry of Industry and Commerce of the State of Rivers, a total of 142 usable questionnaires were administered at 10 selected hotels in Port Harcourt. The findings indicate that social intelligence 


\section{EPRA International Journal of Environmental Economics, Commerce and Educational Management Journal DOI: 10.36713/epra0414 |ISI I.F Value: 0.815|SJIF Impact Factor (2020): 7.572 \\ Volume: 7| Issue: 3 | October 2020}

and entrepreneurial performance have a positive relationship. On the basis of the findings, the following recommendations have been made.

Alsaqri (2014) reviewed entrepreneurial performance and Burnout, together with market shares in Saudi Arabia, discovered that entrepreneurial performance is significantly linked to market share, job stress (uncertainty of treatment) and burn-out with psychometric measures of job stress, burn-out and market share among a population of 297 nurses.

Kumar et al. (2014) examined the impact of the Development Instrument on the performance of entrepreneurship in selected organizations in Port Harcourt, Rivers State, an organization. The instrument was finalized with 76 items under 21 sub-factors of'member entrepreneurial performance.' Back in the organization, they found that member entrepreneurial performance is related to many key areas of organizational behavior and management, such as motivation, leadership, organizational culture, work ethic, employee relationships, organizational policies, and organizational engagement.

(2015) from Wargo Sugleris. In association with retirement among older registered nurses, the determinants of market share, work environment and successful aging were examined. And among these variables used, there was a statistically significant association.

In 2014, Tourangeau et al. This study shed light on the concept of the work environment and other aspects affecting the faculty of the workplace, and a questionnaire with work measures, work environment, market share, burnout and ITR was completed by the participants. Regression tests were carried out to test the model. In the ITR nurse faculty for five years, ten of the 26 independent variables explained 25.4 per cent of the variance. These variables included: proximity to retirement, quality of peer relations, full-time employment, satisfaction with worklife, quality of education, job satisfaction, access to education organizations' financial support, access to the human resources required, and unionization.

(2012) Johari.-Yes. Assess the business performance impact of work environment practices. Four aspects of the HRM practices examined in this study are training and development, career development, compensation and benefits and performance assessment. A survey was conducted among manufacturing company employees in the Northern Region of the Malaysian Peninsula. For data analysis, a total of 184 questionnaires have been returned and used. Based on the statistical tests conducted, the results indicated that only compensation and benefits had a positive impact on the respondents' entrepreneurial performance. Discussions discussed the significance of compensation and benefits among respondents for promoting entrepreneurial performance.

Based on a small survey of employees across four different industries in New Zealand, Markey et al . (2012) estimated the effect of the quality of the work environment on the employee's intention to quit. Existing literature findings are only supported by results if staff perceive their QWE to be good; if staff perceive their QWE to be poor, the current policy implications could be toothless. This suggests that for shaping quitting intentions, QWE is an important policy focus.

In order to investigate the relationship between market share and job design, work techniques, workplace motivation, physical environment, leadership and communication styles, rewards and recognition, Baloch (2009) evaluated the impact of market share on employee motivation and turn over intention in different organizations. The analysis also focused on drawing conclusions that have an effect on productivity from the relationship between market share and organizational performance. The study found that the variables used in the study had a positive association.

Uh, Kwenin et al. (2013), Vodafone Ghana Limited evaluated the effect of employee remuneration, market share and human resource policies on employee retention. There were 142 Vodafone Ghana Limited employees surveyed in the study. Data collection was performed through personal contact by means of a semi-structured questionnaire. Using descriptive statistics and Pearson Chi-square, the data was analysed. Results have shown that when organizations' reward systems are adequate, not only do they lead to equity, but retention increases.

The association between the working environment, career development opportunities and employee retention in Vodafone Ghana Limited was evaluated by Kwenin (2013). 142 employees were involved in the study, representing 10 percent of the 1,420 target population. Data was mainly collected through a semi-structured questionnaire. A descriptive, specifically cross-sectional, research survey was adopted by the paper. Using Descriptive Statistics, the data was analysed. To establish the relationship between the variables, the Pearson Correlation Coefficient was used. The results showed that the working environment and career development opportunities had a positive relationship with the retention of employees and thus had an impact on the decision of employees to stay at Vodafone Ghana Limited.

The relationship between employee organizational performance and organizational commitment was evaluated by Masemola (2011). The study's target population was the University of Employees of Limpopo, divided 


\section{EPRA International Journal of Environmental Economics, Commerce and Educational Management Journal DOI: 10.36713/epra0414 |ISI I.F Value: 0.815|SJIF Impact Factor (2020): 7.572 \\ Volume: 7| Issue: 3 | October 2020}

into three categories, i.e. Personnel in academic, administrative and support. The study used a random sampling method. To collect data, a questionnaire was used, with a combination of closed and open questions. The findings showed that the respondents were not satisfied with their job and had a low dedication to organizing and some plans to leave the university.

Lee et al, Lee et al. (2012) evaluated the factors that influence hotel staff's organizational performance, using linear structural modeling to explore the factors that influence hotel staff's organizational performance in Taiwan. There were a total of 400 questionnaires distributed to hotel employees. Of these, 350 were valid samples, with an 87.50 per cent valid return rate. The study found that more harmonious hotel staff relationships and a higher level of satisfaction with their work environment have a significant positive impact on market share and a higher level of organizational engagement among hotel staff has a significant negative impact on the performance of the organization.

In relation to environmental factors, Paulsen (2014 ) assessed the organizational performance of the organization using primary data sources and a sample of 128 participants in the SPSS analysis. Market shares, leadership and disease absenteeism were the predictors, and the beta value of the predictor was found to have varying degrees of significance for staff in the two age groups. In the current sample, optimism and self-efficacy were not identified as predictors of organizational performance.

\section{METHODOLOGY}

Research Design: The cross-section survey design will be used, which is an aspect of the quasi-experimental research design, as it seeks to evaluate multiple variables over a single time period.

Population for the Study: The population of this study will be drawn from the management of Bottled Water companies in Port Harcourt, Neat Zim Table Water, Evapotentiary and La Sien Bottling Company Limited.

Sample Size: This study used the technique of non-probability sampling. As a result of a process that does not give all individuals in the population the same study based on the convenience of the researcher as the study is carried out within the confines of Port Harcourt, Rivers State..

Sampling Technique: The sample size will be determine by using the Taro Yamanes formula at a 0.05 level of significance I.e. 95\% confidence level. The Taro Yamanes Formular is shown as:

$\mathrm{n} \quad=\frac{\mathrm{N}}{1+\mathrm{N}(\mathrm{e}) 2}$

Where:

$\mathrm{n}=$ the sample size to be determined

$\mathrm{N}=$ the population of the study

$\mathrm{e}=$ Limit of the error acceptable for the study $=5 \%$

$1=$ constant

These sample firms were selected on the basis of their accessibility and efficient performance, as they are generally rated and recommended in the State (Rivers). It is estimated that the number of house respondents is up to 180 cumulatively. Therefore, using the Taro Yamene Formula Above, we're going to have a situation where:

$\mathrm{n}=$ ?

$\mathrm{N}=143$

$1=$ Constant unit

$\mathrm{e}=0.05$

$\mathrm{n} \quad=$ 143

$\mathrm{n} \quad=\quad \frac{143}{1+143(0.0025)}$

$1+143(0.0025)$

$\mathrm{n} \quad=\quad \frac{143}{1+0.3575}$

$1+0.3575$

$\mathrm{n} \quad=\quad \frac{143}{1.3575}$

1.3575

$\mathrm{n}=105.34 \Omega 105$

Which signifies that 105 questioneers will be distributed as deciphered above and distributed below 


\begin{tabular}{|l|l|c|c|}
\hline & & \multicolumn{2}{|c|}{ Distribution Of Respondents } \\
\hline $\mathbf{S} / \mathbf{N}$ & Institution & Respondents & Total \\
\hline 1 & Neat Zim Table Water & 79 & 79 \\
\hline 2 & Evapotential shops & 25 & 25 \\
\hline 3 & La sien Bottling Company Limited & 39 & 39 \\
\hline & TOTAL & 143 & 143 \\
\hline
\end{tabular}

Source: Rivers State Business Registry (2019)

Data Collection Method: This study will use the primary data source to be obtained from the respondents through a carefully structured questionnaire and secondary data to be collected from textbooks, articles, journals, online publications and interviews.

Operational Measures of Variables: In this study, our predictor variable is Work Place Business Environment and will be measured using: internal and external environments. While the criterion is variable, entrepreneurial performance will be measured using productivity and customer satisfaction. Both variables will be ranked to allow the researcher to determine the existence of a correlation. Response modes will be based on the 5 point Likert scale of $5=$ Strongly Accept, $4=$ Accept, $3=$ Neutral, $2=$ Disagree and $1=$ Strongly Disagree. Specifically, The dimensions will include 15 questions (items) which will be adapted from the 32-item Business Environment Questionnaire (BEQ) of Ombaka and Machuki (2015) but will be refined to a 5-point scale as it originally consists of a 7-point scale to bring it into line with the Measures which will involve 6 questions ( 3 each) adapted from the entrepreneurial output scale of Kinnu (2014).

\section{Validity and Reliability of Research Instruments}

Validity and reliability of the instruments are of critical importance to this study.

Validity according to Kumar ( 2005) is the ability of the instrument to measure what it was designed to measure. The validity of the study is in two phases.:

Content Validity: In undertaking this form of validation test, the applied research questionnaire was subject to facial validity in order to ensure that the instruments used were capable of doing what was expected to be done in this study, given to the two senior researchers for validation, and a total of 4 other experts in the field were consulted ..

Construct Validity: This validity came from a pilot test carried out using 2 academic staff at the University of Porthacourt, involving a miniature statistical analysis, in order to test the adequacy of the dimensions and measures pertaining to the underlying subject, the response of which led to the modification of certain items prior to the administration to the respondents,

Reliability analysis was performed on data using the Cronbach Alpha coefficient to assess the degree of consistency of the scale, taking into account the nature of the reactions used to construct the scales. Alpha values of 0.70 and above will be accepted in order to ensure a higher set of reliability among employee variables.

Data Analysis Technique: The Spearman rank order correlation coefficient will be used to analyze the data obtained from the questionnaire, which will allow the researcher to examine the relationship between business environments and entrepreneurial performance. All statistical analysis will be carried out using version 22 of the Statistical Package for Social Sciences (SPSS).

Decision Criteria: for Spearman's rank order correlation coefficient is:

Reject null hypothesis if Spearman's rho coefficient is bigger than critical value (CV)

Fail to reject null hypothesis if Spearman's rho coefficient is smaller or equals to critical value 
Criteria

$\mathrm{r}_{\mathrm{s}}>\mathrm{CV}$

$\mathrm{r}_{\mathrm{s}} \leq \mathrm{CV}$
Decision

Reject the null hypothesis

Fail to reject the null hypothesis

\section{DATA ANALYSIS AND INTERPRETATION}

\section{Profile of Respondents}

The sample distribution of the Respondents indicates that a total of 50 questionnaires, representing 54.9 per cent of the respondents, were distributed to the Neat Zim Table Water respondents, while 16, representing 17.6 per cent of the respondents, were from Rivers State University of Science and Technology, and 25, representing 27.5 per cent of the respondents, were from La sien Bottling Compa. The research sample consists of 81 males and 10 females. Indicating a higher percentage of male ( 89.0 per cent) to female (11.0) in the sample. Showing that there is a high level of gender gap in the management of selected bottled water companies. 3 were identified as single, with the corresponding 3.3 percent being divorced and widowed. This means that most of the respondents were married.

\section{Hypothesis Testing \\ Spearman Correlation Matrix Correlations}

\begin{tabular}{|c|c|c|c|c|c|c|c|}
\hline & & & $\begin{array}{c}\text { Internal } \\
\text { environm } \\
\text { ent } \\
\end{array}$ & $\begin{array}{c}\text { External } \\
\text { environment }\end{array}$ & $\begin{array}{c}\text { Relationshi } \\
\text { p with co- } \\
\text { workerss } \\
\end{array}$ & $\begin{array}{c}\text { Customer } \\
\text { satisfactio } \\
\text { n } \\
\end{array}$ & $\begin{array}{l}\text { Market } \\
\text { shares }\end{array}$ \\
\hline & & Correlation & 1.000 & $.889^{* *}$ & $.617^{* *}$ & $.898^{* *}$ & $.801^{* *}$ \\
\hline & $\begin{array}{l}\text { Internal } \\
\text { environment }\end{array}$ & Coeffrclent & & 000 & 000 & 000 & 000 \\
\hline & & $\mathrm{N}$ & 105 & 105 & 105 & 105 & 105 \\
\hline & Exter & $\begin{array}{l}\text { Correlation } \\
\text { Coefficient }\end{array}$ & $.889^{* *}$ & 1.000 & $.849^{* *}$ & $.957^{* *}$ & $.936^{* *}$ \\
\hline & environment & Sig. (2-tailed) & .000 & 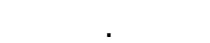 & .000 & .000 & .000 \\
\hline & & $\mathrm{N}$ & 105 & 105 & 105 & 105 & 105 \\
\hline $\mathrm{ma}$ & Relationship & $\begin{array}{l}\text { Correlation } \\
\text { Coefficient }\end{array}$ & $.617^{* *}$ & $.849^{* *}$ & 1.000 & $.814^{* *}$ & $.841^{* *}$ \\
\hline n's rho & With CO- & Sig. (2-tailed) & .000 & .000 & . & .000 & .000 \\
\hline & & $\mathrm{N}$ & 105 & 105 & 105 & 105 & 105 \\
\hline & Customer & $\begin{array}{l}\text { Correlation } \\
\text { Coefficient }\end{array}$ & $.898^{* *}$ & $.957^{* *}$ & $.814^{* *}$ & 1.000 & $.913^{* *}$ \\
\hline & satisfaction & Sig. (2-tailed) & .000 & .000 & .000 & . & .000 \\
\hline & & $\mathrm{N}$ & 105 & 105 & 105 & 105 & 105 \\
\hline & & $\begin{array}{l}\text { Correlation } \\
\text { Coefficient }\end{array}$ & $.801^{* *}$ & $.936^{* *}$ & $.841^{* *}$ & $.91^{* *}$ & 1.000 \\
\hline & Market SHares & Sig. (2-tailed) & .000 & .000 & .000 & .000 & . \\
\hline & & $\mathrm{N}$ & 105 & 105 & 105 & 105 & 105 \\
\hline
\end{tabular}

**. Correlation is significant at the 0.05 level (2-tailed).

Source: Research data, 2020 (SPSS-22 output)

\section{Hypothesis One}

$\mathbf{H}_{\mathrm{o} 1}$ : There exists no significant relationship between internal environment and Customer satisfaction of bottled water companies in Nigeria.

The association between the internal environment and Customer satisfaction of selected Bottled Water companies in Port Harcourt. Where rho $=0.898$ and $p=0.000$. The findings show a very positive and significant association between the two variables (where ** is of significance at 0.01 and $\mathrm{p}<0.05$ ); therefore, based on the criterion of nullhypothetical rejection of $p<0.05$, we reject null and reiterate that there is a significant relationship between the internal environment and the customer satisfaction of bottled water companies in Nigeria. 


\section{Hypothesis Two}

$\mathbf{H}_{\mathbf{0} 2}$ : There is no significant relationship between External environment and Customer satisfaction of bottled water companies in Nigeria.

Analysis of the association between the external environment and Customer satisfaction in selected Bottled Water companies in Port Harcourt. Where rho $=0,957$ and $p=0.000$. The findings show a very positive and significant association between the two variables (where $* *$ is of significance at 0.01 and $p<0.05$ ); therefore, based on the criterion of null-hypothetical rejection of $p<0.05$, we reject null and reiterate that there is a significant relationship between the external environment and the customer satisfaction of bottled water companies in Nigeria.

Hypothesis Three

$\mathbf{H}_{\mathbf{0} 3}$ : There is no significant relationship between Internal environment and Market shares of bottled water companies in Nigeria.

Analysis of the association between the internal environment and the market share of selected bottled water companies in Port Harcourt Where rho $=.801$ and $p=0.000$. The findings show a very positive and significant association between the two variables (where $* *$ is of significance at 0.01 and $\mathrm{p}<0.05$ ); therefore, based on the criterion of null-hypothetical rejection of the statement at $\mathrm{p}<0.05$, we reject the null and reiterate that there is a significant relationship between the internal environment and the market shares of bottled water companies in Nigeria.

\section{Hypothesis Four}

$\mathbf{H}_{04}$ : There is no significant relationship between External environment and Market shares of bottled water companies in Nigeria.

Analysis of the association between the external environment and the market share of selected bottled water companies in Port Harcourt Where rho $=.936$ and $p=0.000$. The findings show a very positive and significant association between the two variables (where $* *$ is of significance at 0.01 and $p<0.05$ ); therefore, based on the criterion of null-hypothetical rejection of the statement at $\mathrm{p}<0.05$, we reject the null and reiterate that there is a significant relationship between the external environment and the market shares of Nigerian organizations.

Hypothesis Five

$\mathbf{H}_{05}$ : There is no significant influence of Organizational Structure on the association between Business Environment and Entrepreneurial performance of sampled bottled water companies in an Organization.

Partial Correlation (Moderating Role of Organizational Structure). Correlations

\begin{tabular}{|lll|c|c|}
\hline \multicolumn{2}{c|}{ Control Variables } & Environment & $\begin{array}{c}\text { Business } \\
\text { Environments }\end{array}$ \\
\hline & \multirow{3}{*}{ Environment } & Correlation & 1.000 & -.074 \\
Organizational & & Significance (2-tailed) &. & .488 \\
Structure & $\mathrm{df}$ & 0 & 140 \\
& & Correlation & -.074 & 1.000 \\
& \multirow{3}{*}{ Business Environments } & Significance (2-tailed) & .488 &. \\
& & $\mathrm{df}$ & 140 & 0 \\
\hline
\end{tabular}

Source: Research data, 2020.

Based on the output in Table 4.22 above, it could be assumed that the Organizational Structure has no moderating influence on the relationship between the Business Environments and the Environment in the employed institution on the basis of a correlation coefficient of -0.074 at a probability level of 0.488 which is greater than the significance level of 0.05 ( 5 per cent), therefore we do not reject the nullity of the value.

\section{CONCLUSION}

There is no doubt on the basis of the findings of this paper that the external business environment has an impact on entrepreneurial performance. The study concluded that bottled water companies should understand all of this type of business environment and its implications for the entrepreneurial performance of their businesses and update their knowledge base and skills in order to meet the expected changes in the realm of their business and also call for constant monitoring and environmental scanning. 


\section{EPRA International Journal of Environmental Economics, Commerce and Educational Management Journal DOI: 10.36713/epra0414 |ISI I.F Value: 0.815|SJIF Impact Factor (2020): 7.572 Volume: 7| Issue: 3 | October 2020}

Theoretically, this study provided some empirical evidence of the relationship between the working environment and organizational entrepreneurial performance. The results of this study have also been added to the literature on business practices and organizational entrepreneurial performance. As far as the practical contribution is concerned, the results of the research validated the notion that compensation and the relationship with the environment (both internal and external) are of the utmost importance in enhancing firm performance.

\section{Recommendations}

Therefore, in order to reduce environmental uncertainties, the following recommendations are suggested:

1. Organizations should improve their level of motivation, since it is clear that rewards tend to increase the performance of workers. Employee satisfaction should be maintained within the organization.

2. Employees should be well trained to improve performance. Good supervision of employees will improve the performance of the job. The manager tends to have the ability to control, plan and organize his or her company when he or she is well trained in the task.

3. The organization should provide rewards and benefits to workers who have the right to do so, as this will improve employee satisfaction, which will boost entrepreneurial performance. It will encourage workers to take their work as important as possible. Management should also decentralize power or authority; they should learn to listen to the opinion of workers because it allows for a cordial relationship.

4. Finally, management must understand government policies or regulations because they have an impact on entrepreneurial performance.

\section{REFERENCES}

1. Adebayo, I. O., Ogunyomi, P. O., \& Ojodu, H.O. (2005). Introduction to Business Management, 2nd ed., Lagos, AbilejoPrinting Press.

2. Adeleke A (2013). Business policy and strategy Lagos: Concept publication ltd

3. Adeoye, M.O (2012). Impact of Business Environment on Entrepreneurship performance in Nigeria. Computer Information System Development Information and Allied Research, 4(4), 59-66

4. Agullar F.J (1967). Scanning the business. New York: MC Graw-Hill

5. Ajayi, A. (2018). Impact of external business environment on organisational performance of small and medium scale enterprises in Osun State, Nigeria. Scholedge International Journal of Business Policy \& Governance, 3(10), 155-166.

6. Baloch, Q. B. (2009). Effects of job satisfaction on employee's motivation \& turn over intentions. Journal of Managerial Sciences, 2(1), 1-21.

7. Bothma, C. F. C., \& Roodt, G. (2012). The Validation of the Organizational performance Scale. SA Journal of Human Resources Management, 11(1), Art.507, 12 pages. Doi: 10.4102/ sajhrm.v11i1.507

8. Brewer, C., Kovner, C., Greene, W., Tukov-Shuser, M. \& Djukic, M. (2012). Predictors of actual turnover in a national sample of newly licensed registered nurses employed in hospitals. Journal of Advanced Nursing, 68(3), 521-538.

9. Buchanan, D. A., \& Huczynski, A. A. (2019). Organizational behaviour. Pearson UK.

10. Busck, O., Knudsen, H., \& Lind, J. (2010). The transformation of employee participation: Consequences for the work environment. Economic and Industrial Democracy.

11. Cappelli, P. (2008). Talent on Demand: Managing Talent in an Age of Uncertainty. Boston, MA: Harvard Business School Press.

12. Eiken, \& Saksvik, P. Ø. (2011). Det psykososiale arbeidsmilj $\varnothing$ - hvor har det blitt av denvsosiale dimensjonen? In Saksvik, P. Ø. (Ed.), Arbeids- og organisasjonspsykologi:vAktuelle tema til inspirasjon for et bedre arbeidsliv (pp.186213). Oslo: Cappelen Damm Akademisk.

13. Eketu, C. A \& Ogbu, E. F (2015). Social Intelligence and Employee Entrepreneurial performance. International Journal of Novel Research in Marketing Management and Economics. 2(1), 27-34.

14. Fermando, A. C (2011). Business Environment. Darling Kindersley publications India

15. Ghiselli, R., La Lopa, J., \& Bai, B. (2001). Job satisfaction, life satisfaction, and turnover intent among food-service managers. The Cornell Hotel and Restaurant Administration Quarterly, 42(2), 28-37.

16. Hobfoll, S. E., Johnson, R. J., Ennis, N., \& Jackson, A. P. (2003). Resource Loss, Resource Gain, and Emotional Outcomes Among Inner City Women. Journal of Personality and Social Psychology, 84(3), 632-643.

17. Jackson, S. \& Maslach, C. (1982). After-effects of job-related stress: Families as victims. Journal of Organizational Behavior, 3(1), 63-77.

18. Johari, J. O. H. A. N. I. M., Yean, T. F., Adnan, Z. U. R. I. N. A., Yahya, K. K., \& Ahmad, M. N. (2012). Promoting employee entrepreneurial performance: Do human resource management practices matter. International Journal Economics and Management, 6(2), 396-416.

19. Jones, G.R., \& J.M, George, 2009 "Contemporary management 6th international ed, Mc Graw Hill, New York USA.

20. Kinnu D. (2014). Top management team psychological characteristics, institutional environment, team processes and performance of companies listed in Naurobi Security exchange. 


\section{EPRA International Journal of Environmental Economics, Commerce and Educational Management Journal DOI: 10.36713/epra0414 |ISI I.F Value: 0.815|SJIF Impact Factor (2020): 7.572 Volume: 7| Issue: 3 | October 2020}

21. Kobia M, \& Muhammed (2006). The Kenya experience with performance contracting, African association for public administration and management $28^{\text {th }}$ AAAAM Annual Round Table Conference Arusha, Tanzania

22. Kristof-Brown, A. \& Jansen, K. (2007). Issues of person-organization fit. In C. Ostrov \& T. Judge (Eds.), Perspectives on organizational fit. New York, NY: Taylor \& Francis.

23. Kumar, D., \& Govindarajo, N. S. (2014). Instrument Development "Entrepreneurial performance instrument"'(ISI). Asian Social Science, 10(12), 149.

24. Kwenin, D. O., Muathe, S., \& Nzulwa, R. (2013). The influence of employee rewards, human resource policies and job satisfaction on the retention of employees in Vodafone Ghana Limited. European Journal of Business and Management, 5(12), 13-20.

25. Lee, C. C., Huang, S. H., \& Zhao, C. Y. (2012). A study on factors affecting organizational performance of hotel empolyees. Asian Economic and Financial Review, 2(7), 866.

26. Maduki V.N and Aosa E (2011). The influence of external environment on the performance of publicity quoted companies in Kenya, Business Administration and Management Journal 1(7), 205-218.

27. Markey, R., Ravenswood, K., \& Webber, D. J. (2012). The impact of the quality of the work environment on employees' intention to quit. Economics Working Paper Series, 1220.

28. Masemola, S. E. (2011). Employee organizational performances, organisational commitment and job satisfaction in a post-merger tertiary institution: the case of the University of Limpopo (Doctoral dissertation, University of Limpopo (Turfloop Campus).

29. Mishra, D., Luo, Z., Hazen, B., Hassini, E., \& Foropon, C. (2019). Organizational capabilities that enable big data and predictive analytics diffusion and organizational performance: A resource-based perspective. Management Decision.

30. Murgor, P.K (2014). External Environment, firm capabilities strategies responses of large scale manufacturing firms in Kenya, University of Nairobi, unpublished PhD. Thesis.

31. Ogundele O.J.K (2005). Management and Organization. Theory and Behaviours" Sabte Book series, Lagos Nigeria

32. Ogundele, O. J. K., \& Opeifa, A. Z. (2004). The Influence of External Political Environment on the Processes of Entrepreneurship. The Nigerian Academic Forum: A Multidisciplinary Journal, 7 (5

33. Ongeti W.J (2014). organizational resources, corporate Governance and performance of Kenya State owned corporations. University of Nairobi.

34. Osuagwu L. (2001) Small business and entrepreneurship management” Grey Resources Limited Lagos.

35. Otokiti, S.O., \& M.O, Awodun (2003). The master strategist management style in a Turbulent Business Environment" Punmark Nigeria Limited, Lagos.

36. Paulsen, M. (2014). Organizational performance among Engineering Employees: A Question about Psychosocial Work Environment Factors and Age?: A quantitative study conducted on a global oil and gas company (Master's thesis, Norges teknisk-naturvitenskapelige universitet, Fakultet for samfunnsvitenskap og teknologiledelse, Psykologisk institutt).

37. Rizwan, M., Arshad, M. Q., Munir, H. M. A., Iqbal, F., \& Hussain, A. (2014). Determinants of Employees intention to leave: A Study from Pakistan. International Journal of Human Resource Studies, 4(3), 1.

38. Robbins, S. P. (2003) Organizational Behavior, New Jersey: Pearson Education International, Inc.

39. Selden, S.C., \& J.E, Sowa (2004). Testing a multi-dimensional model of entrepreneurial performance prospects and problems" Journal of Public Administration Research Theory 14(3). 395-416

40. Sell, L., \& Cleal, B. (2011). Job satisfaction, work environment, and rewards: Motivational theory revisited. Labour, 25(1), 1-23.

41. Shaikh, S. (2010). Business Environment for Universities and Autonomous colleges of Odisha Pearson Edneation inc.

42. Sweetman, D., \& Luthans, F. (2010). The Power of Positive Psychology: Psychological Capital and Work Engagement. In A.B. Bakker \& M.P. Leiter (Eds.), Work Engagement: A Handbook of Essential Theory and Research (pp. 54-68). New York: Psychology Press.

43. Tacheva, 5 (2007). Top management team internationalization construct development and empirical test. Welch J \& Welch $\mathrm{S}$ (2005). winning Harper Business, New York

44. Tourangeau, A., Saari, M., Patterson, E., Ferron, E. M., Thomson, H., Widger, K., \& MacMillan, K. (2014). Work, work environments and other factors influencing nurse faculty intention to remain employed: A cross-sectional study. Nurse education today, 34(6), 940-947.

45. Tremblay, M. A., \& Messervey, D. (2010). The Job Demands-Resources Model: Further Evidence for the Buffering Effect of Personal Resources. SA Journal of Industrial Psychology, 37(2).

46. Wargo-Sugleris, M. (2015). Job Satisfaction, Work Environment, and Successful Aging: Determinants to Remain in Older Acute Care Nurses. 